\title{
CONTROLE SOCIAL DAS MIGRAÇÕES E GESTÃO DA DIVERSIDADE. REFLEXÕES PARA A CONSTRUÇÃO DE UM NOVO MARCO NORMATIVO MIGRATÓRIO BRASILEIRO
}

SOCIAL CONTROL OF MIGRATION AND MANAGEMENT OF DIVERSITY. REFLECTIONS FOR THE CONSTRUCTION OF A NEW LEGAL MIGRATORY BRAZILIAN FRAMEWORK

CONTROL SOCIAL DE LAS MIGRACIONES Y GESTIÓN DE LA DIVERSIDAD. REFLEXIONES PARA LA CONSTRUCCIÓN DE UN NUEVO MARCO NORMATIVO MIGRATORIO BRASILEÑO

André Leonardo Copetti Santos ${ }^{1}$

$1 \quad$ André Leonardo Copetti Santos. Pós-Doutorando (UNISINOS e Universidade de Santiago do Chile). Doutor pela UNISINOS (2004). Professor e pesquisador dos PPGDs da URISAN (Santo Ângelo, RS) e da UNIJUÍ (Ijuí, RS). Coordenador Executivo do PPGD/URISAN. Email: andre.co.petti@hotmail.com 
Resumo: O Brasil é um dos países latino-americanos com maior recepção migratória nas últimas décadas. Um dos principais efeitos desse fenômeno é o aumento da diversidade étnica das sociedades receptoras e, consequentemente, o surgimento de inúmeros problemas de adaptação dos imigrantes. As soluções políticas e jurídicas positivadas para tais questões são genericamente dadas por modelos teórico/práticos de integração étnica de populações migrantes e de governabilidade de fluxos de pessoas. $O$ presente trabalho buscou analisar quais destes modelos estão materializados no sistema jurídico brasileiro e, a partir disto, refletir acerca de possíveis novos enfoques sobre os fenômenos migratórios e novas funcionalidades regulatórias adequadas a um marco de direitos humanos. A abordagem metodológica utilizada é sistêmica e, ao final, espera-se, como resultado, a delimitação de algumas áreas de discussão que possibilitem a recolocação do problema da regulação jurídica dos processos migratórios em termos que se afastem de políticas meramente nacionalistas e securitárias.

Palavras-chave: Migrações. Diversidade. Gestão. Políticas públicas. Controle social.

Abstract: Brazil is one of Latin American countries with the highest immigration in recent decades. One of the main effects of this phenomenon is the increasing ethnic diversity of the host societies, and hence, the emergence of numerous adaptation problems among immigrants. The political and legal solutions validated for such questions are generally given by theoretical/ practical models of ethnic integration of migrant populations and governance of flows of people. This paper looks at which of these theoretical/practical models are materialized in the Brazilian legal system and, based on this, reflects on the possible new approaches on the migration phenomenon and new regulatory functionalities adequate to a human rights framework. The methodological approach used is systemic, and the expected result is the definition of some areas for discussion that enable the replacement of the problem of legal regulation of migration 
processes in terms that move away from purely nationalist and security policies.

Keywords: Migrations. Diversity. Management. Public policies. Social control.

Resumen: Brasil es uno de los países latinoamericanos con mayor recepción migratoria en las últimas décadas. Uno de los principales efectos de ese fenómeno es el aumento de la diversidad étnica de las sociedades receptoras y, consecuentemente, el surgimiento de innumerables problemas de adaptación de los inmigrantes. Las soluciones políticas y jurídicas positivadas para tales cuestiones están dadas genéricamente por modelos teórico prácticos de integración étnica de poblaciones migrantes y de gobernabilidad del flujo de personas. El presente trabajo buscó analizar cuáles de estos modelos están materializados en el sistema jurídico brasileño y, a partir de ello, reflexionar acerca de posibles nuevos enfoques sobre los fenómenos migratorios y nuevas funcionalidades regulatorias adecuadas a un marco de derechos humanos. El abordaje metodológico utilizado es sistémico y al final se espera, como resultado, la delimitación de algunas áreas de discusión que posibiliten el replanteo del problema de la regulación jurídica de los procesos migratorios en términos que se alejen de políticas meramente nacionalistas y de seguros.

Palabras clave: Migraciones. Diversidad. Gestión. Políticas públicas. Control social. 


\section{PRELÚDIO DA PROBLEMATIZAÇÃO: A GESTÃO DA PARTICIPAÇÃO DO MIGRANTE NA SOCIEDADE RECEPTORA E O PAPEL DOS SISTEMAS NORMATIVOS NACIONAIS}

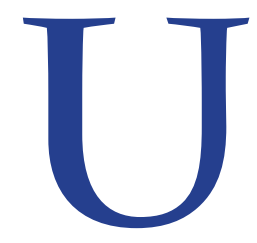

ma das características mais marcantes dos fenômenos migratórios contemporâneos, numa época que alguns autores chamam a "era da migração"2, é a diversidade étnica e cultural da população de alguns países que têm se constituído em receptores de migrantes, chegando alguns investigadores a falar em "superdiversidade"3. Esta situação de exacerbação da diversidade, em função da proliferação dos fluxos migratórios, tem contribuído fortemente para a materialização de uma das facetas mais graves do que Mármora denomina como "crise de governabilidade migratória", qual seja, o problema das respostas discriminatórias em relação ao migrante de vastos setores da população dos países receptores. Constata-se, assim, que o problema da participação do migrante na sociedade receptora é um dos mais relevantes problemas de governabilidade a ser enfrentado pelos Estados e pelas sociedades que estão envolvidos nos processos de mobilidade.

O rol de questões que estão abarcadas na questão da participação do migrante não é simples, englobando decisões que envolvem o exercício dos seus direitos de cidadania; as modalidades de participação social, cultural e econômica; as formas de integração à sociedade de recepção e, até mesmo, a possível reintegração ao seu regresso à sociedade de origem.

No plano ideal, o enfrentamento desse rol de problemas que envolve a participação e a integração dos migrantes nas sociedades receptoras tem sido objeto de dois grandes grupos de modelos teórico-práticos. A referência aqui é dirigida especificamente aos modelos ideais de integração étnica (assimilação, melting pot e pluralismo cultural) e de governabilidade migratória (securitização, benefícios compartilhados e desenvolvimento humano para as migrações). Estes

2 CASTLES, Stephen; HAAS, Hein de; MILLER, Mark J. The Age of Migration: International Population Movements in the Modern World. 15. ed. New York: The Guilford Press, 2013.

3 VERTOVEC, Steven. "Superdiversity' and its implications". In: Ethnic and racial studies. v. 30, n. 6, 2007, pp. 1024-1054. 
standarts ideais apresentam zonas de interseção, que aparecem de forma mais clara nos processos concretos de execução de políticas governamentais de gestão das migrações.

Estando o Brasil, na atualidade, no início de um processo de discussão acerca de uma nova legislação migratória, propõe-se no presente estudo: primeiro, uma análise da questão da diversidade decorrente dos fluxos migratórios; segundo, uma aproximação a esses diferentes modelos de abordagem do problema da diversidade; terceiro, um exame dos marcos normativos migratórios argentino e brasileiro à luz desses modelos ideais; e, por fim, uma projeção do que pode vir a ser um modelo humanista e democrático de gestão das migrações para o Brasil, mais especificamente em relação ao problema da participação/integração dos migrantes.

\section{MIGRAÇÕES CONTEMPORÂNEAS, COMPLEXIFICAÇÃO DA DIVERSIDADE E IDENTIDADE DOS MIGRANTES}

O contraste qualitativo das medidas políticas e jurídicas adotadas por diferentes países, em distintas épocas, em relação aos processos de mobilidade humana, as quais se materializam desde aberturas e tolerâncias aos migrantes em tempos de boa economia à relutância e até mesmo xenofobia e ressentimento, particularmente em tempos de desaceleração econômica, desemprego e inseguridade financeira, revelam o quão contraditório e controverso é o tema da mobilidade internacional de pessoas.

Pela variedade de problemas que emergem nesses processos, as migrações têm sido encaradas de muitos e diferentes pontos de vista. Numerosos estudos têm considerado suas implicações históricas, demográficas, culturais, religiosas, políticas, ideológicas, sociológicas, jurídicas etc., enredos que são, sem dúvida, de transcendental importância 4 .

4 Ver a respeito BRETTEL, Caroline B.; HOLLIFIELD, James F. (Eds.). Migration Theories of International Migration: A Review and Appraisal Theory. Talking Across Disciplines. 2. ed. New York/London: Routledge, 2008; KUREKOVA, Lucia. Theories of migration: Conceptual review and empirical testing in the context of the EU East-West flows. London: University College London, 2011; MASSEY, Douglas S., ARANGO, Joaquin et alli. Theories of International Migration: A Review and Appraisal. In: Population and Development 
No âmbito estatal, as maiores preocupações referem-se, fundamentalmente, ao controle dos fluxos pelos países receptores, especialmente de entrada de imigrantes pobres em seus territórios e, pelo menos nos últimos tempos, tais preocupações se materializaram em medidas políticas e jurídicas, penais e administrativas, fortemente repressivas ${ }^{5}$.

Não se pode ingenuamente pensar que os problemas envolvendo estes fenômenos comecem e acabem com o controle dos fluxos, especialmente de entradas. É preciso considerar que, uma vez estando o imigrante instalado no país de destino, a gama de problemas possíveis de serem por ele enfrentados é bastante grande. Nos últimos anos, por exemplo, o tema começou até mesmo a interessar aos profissionais da saúde mental, em virtude do alto número de migrantes que passaram a demandar seus serviços pela ocorrência de transtornos psíquicos e por problemas que podiam ter uma relação direta com a migração. De acordo com Grimberg e Grimberg, por exemplo, não se pode subestimar, ainda quando sua avaliação seja difícil, a incidência de uma problemática psicológica particular, que afeta a pessoa que "migra" e o seu entorno (o antigo e o novo) e se relaciona tanto com as motivações da migração como com suas consequências ${ }^{6}$.

Desde essa perspectiva crítico-problemática, não se pode evitar que um dos principais problemas atinentes aos processos migratórios diz respeito à diferença cultural a ser vivenciada pelo imigrante diante da cultura ou das culturas do país recebedor e as consequências daí emergentes em relação à configuração de sua própria identidade. É importante tomar em conta o fato inquestionável de que, como bem observa Harvey, muitos Estados do mundo atual se caracterizam por ter populações multiétnicas, constituídas lenta ou rapidamente7. Assim, inobstante as diferenciações que podem ser feitas em relação à variedade de migrações que ocorreram ao longo da história, em razão das distintas variáveis inerentes

Review, v. 19, n. 3, Sep., 1993, pp. 431-466; SOLIMANO, Andrés. International Migrations in the Age of Crisis and Globalizations. Historical and Recent Experiences. Cambridge: Cambridge University Press, 2010.

5 Sobre distintos modelos repressivos dos processos de mobilidade humana internacional ver a respeito SANTOS, A. L. C. A repressão das diásporas em tempos globais e os direitos humanos dos migrantes. In: BEDIN, Gilmar Antonio (Org.). Cidadania, Direitos Humanos e Equidade. Ijuí: Editora UNIJUÍ, 2012.

6 GRIMBERG, L.; GRIMBERG, R. Migración y Exilio. Estudio psicoanalítico. Madrid: Editorial Biblioteca Nueva, S. L., 1996, p. 15.

7 HARVEY, David. Sociologia. 6. ed. Porto Alegre: Penso, 2012, p. 459. 
a cada caso - populações envolvidas, motivações, estratégias, logísticas etc. -, há uma constante histórica que nelas se afirmou como um elemento imanente inafastável das composições sociais decorrentes de processos de mobilidade humana: a mescla, maior ou menor, potencial ou concreta de pessoas, grupos, povos, nações com diversidade culturais.

O fato é que o incremento da variedade e da diversidade na composição étnica e cultural dessas novas populações é característico da Modernidade, com uma agudização nos dias atuais em função da aceleração dos fluxos causados pelo desenvolvimento tecnológico, especialmente se se considerar as últimas três ou quatro décadas. Esta configuração pluriétnica e pluricultural de muitos países e cidades foi tomada, por exemplo, por Vertovec para introduzir o termo "superdiversity", a fim de destacar as mudanças às quais se assistiu recentemente na Inglaterra, especialmente salientes na cidade de Londres. A noção de superdiversidade emprega-se para sintetizar uma série de traços que afetam o modo de viver das pessoas. Não só o país de origem ou a etnicidade entram aqui em jogo, mas o conceito abrange aspectos como a condição legal diferencial dos imigrantes (e os direitos associados a cada condição), as pautas de assentamento, seu capital humano e o acesso ao emprego, as diferenças linguísticas e religiosas, o transnacionalismo ou, inclusive, a maneira pela qual respondem a esta diversidade as autoridades, os provedores de serviços e os residentes locais. Mais do que centrar-se na ideia de diversidade, em alusão estrita à etnicidade e à procedência de um país determinado, destaca esse autor a existência de múltiplos elementos que produzem esta superdiversidade, concomitantemente à interação de muitos destes eixos de diferenciação8.

Essa preocupação com a diversidade é objeto de uma recente investigação da Fundação Getúlio Vargas. Em uma séria denominada "Estudos Estratégicos sobre Políticas Públicas, no seu primeiro volume denominado "Imigração como Vetor Estratégico do Desenvolvimento Socioeconômico e Institucional do Brasil", ao estabelecer uma reflexão acerca da elaboração de políticas públicas voltadas para a atração de imigrantes qualificados como vetor do desenvolvimento socioeconômico do país, os pesquisadores da FGV apontam, dentre outras diretrizes a serem consideradas, três que, especificamente, chamam a atenção, por 8 VERTOVEC, Steven. "Superdiversity' and its implications", p. 1027-1028. 
sua relação com a questão da diversidade étnico-cultural que está envolvida nos processos migratórios. São elas: a) a importância de considerar as perspectivas das populações dos países de origem, da sociedade nacional e da própria população migrante para a consecução de políticas responsáveis; b) a necessidade de garantir os direitos humanos para a população de imigrantes; c) e a necessidade de integrá-los harmonicamente na sociedade brasileira. A partir disto, conclui o documento que "a integração harmônica somente será possível dentro de um quadro de sustentabilidade cultural, onde os diferentes sejam somados num quadro social de diversidade cultural" 9 .

É importante considerar que nos processos migratórios os ônus não são somente para o Estado receptor, mas os próprios migrantes têm seus desembolsos. Na visão de Keeley, os migrantes têm tanto custos tangíveis, tais como os gastos com transporte ou com burocracia, abandono de propriedades e liquidação de bens materiais, quanto os custos não tangíveis, por vezes ainda mais relevantes, como a separação de parentes, a dificuldade de adaptação a novas culturas e de integração em sociedades dessemelhantes (grifo nosso) ${ }^{10}$.

O que é preciso ressaltar fortemente, é que a diversidade étnico-cultural das sociedades de países receptores de migrantes e a consequente necessidade de sua administração nos espaços geopolíticos nacionais e transnacionais, pelos mais distintos meios, deve se constituir em elemento de importante preocupação e ação dos poderes públicos, com o intuito de evitar-se que o pluralismo sociocultural, decorrente dos processos migratórios, se constitua em fator de desagregação, degradação e geração de conflitos sociais, mas, noutro sentido, se assente como um componente de desenvolvimento social.

Nesse eixo de preocupação, não se pode deixar de ter em conta que um dos corolários mais imediatos da diversidade sociocultural gerada pelos processos de

9 FUNDAÇÃO GETÚLIO VARGAS. A Imigração como Vetor Estratégico de Desenvolvimento Socioeconômico e Institucional do Brasil. Estudos Estratégicos sobre Políticas Públicas. Rio de Janeiro: FGV, s.d., v. 1. Disponível em: www.fgv.br/fgvprojetos e/ou www. dapp.fgv.br. Acesso em: 15 maio 2014.

10 KEELEY, Brian. The Migration Debate. International Migration: The Human Face of Globalization, OECD Publishing, 2009. Disponível em: http://www.oecd-ilibrary.org/socialissues-migration-health/ international-migration_9789264055780-em. Acessado em: 29 nov. 2013. 
mobilidade humana atinge diretamente a identidade dos migrantes. A capacidade do indivíduo de seguir sentindo-se o mesmo num processo de sucessivas mudanças, mais ou menos longas, mais ou menos traumáticas, forma a base da experiência psíquica da identidade. Implica manter a estabilidade por meio de circunstâncias diversas e de todas as transformações e mudanças do viver.

Acontecimentos que implicam mudanças importantes na vida de um indivíduo, como o da migração, podem converter-se em fatores desencadeantes de ameaças ao sentimento de identidade, ao processo de autopercepção do indivíduo.

O imigrante em sua luta de autopreservação necessita apegar-se a distintos elementos de seu ambiente nativo (objetos familiares, música de sua terra, recordações e sonhos em cujo conteúdo manifesto ressurgem aspectos do país de origem) para manter sua experiência do "sentir-se a si mesmo".

Freud, ao utilizar o termo "identidade" em sua obra, o fez com uma conotação psicossocial. Foi quando tratou de explicar em um discurso seu vínculo com o judaísmo e falou de "obscuras forças emocionais", que eram "tanto mais poderosas quanto menos se as podia expressar com palavras", e uma clara consciência de identidade interior que não está baseada na raça ou na religião, mas em uma atitude comum a um grupo, a viver em oposição e estar livre de prejuízos que obstaculizariam o uso do intelecto. A ideia de Freud remete a uma relação entre o indivíduo e o seu grupo com a conotação de uma persistente "mesmidade" e de um persistente compartilhamento de certo caráter essencial com os outros ${ }^{11}$.

As migrações, especialmente as não desejadas, põem a prova a estabilidade psíquica e emocional dos migrantes. Somente uma boa relação com os objetos internos, a aceitação das perdas e a elaboração das dores e dos lutos poderá permitir uma melhor integração entre os dois países, os dois tempos, o grupo de antes e o atual, o que dará lugar a uma organização e consolidação do sentimento de identidade, que corresponderá a alguém que segue sendo o mesmo apesar das mudanças e das remodelações em sua vida.

11 FREUD, S. Inhbición, sintoma y angustia. In: Obras Completas. v. 20. Buenos Aires: Amorrurtu Ed., 1976. 
Esse elemento de equilíbrio existencial do migrante é muito mais difícil de ser obtido pela ação solipsista do indivíduo afetado pelo deslocamento. Em sentido contrário, quando há uma intervenção de organismos coletivos de apoio, mediante ações sociais integradoras, a tarefa torna-se mais fácil. Aqui o destaque deve ser dado, em especial, às políticas públicas estatais e públicas não estatais que podem aportar um forte apoio ao migrante, minimizando fortemente as perdas causadas pelos processos de deslocamento e proporcionando-Ihe alcançar estados de equilíbrio existencial.

Um dos grandes desafios dos países receptores, que não raro beneficiam-se da mão de obra dos migrantes, é gerir os processos de inserção dos estrangeiros, de modo a criar condições sociais e existenciais que permitam suavizar os processos traumáticos de perda impostos pelo deslocamento; gerir a diversidade de forma a permitir a inclusão do migrante na nova sociedade que lhe está recebendo, sem a imposição de assimilações culturais forçadas, de modo a reduzir ao mínimo as fraturas em sua percepção identitária.

\section{MODELOS TEÓRICO-PRÁTICOS DE INTEGRAÇÃO ÉTNICA}

As possibilidades de aproximação/solução desses tipos de problemas que afetam os migrantes podem ser agrupadas em três grandes modelos teórico-práticos, cujos fundamentos podem ser tomados em conta para a análise e gestão da diversidade étnico-cultural resultante dos processos migratórios, a saber: o modelo da assimilação, o modelo do melting pot e o modelo do pluralismo cultural.

\section{O MODELO DA ASSIMILAÇÃO}

Uma abordagem assimilacionista ${ }^{12}$ sustenta-se sobre a ideia central de que

12 Ver BARKAN, Elliot. Race, Religion and Nationality in American Society: a Model of Ethnicity-From Contact to Assimilation. In: Journal of American Ethnic History, n. 14, 1995, pp. 38-101; BARKAN, Elliot. Introduction: Immigration, Incorporation, Assimilation and the Limits of Transnationalism. In: Journal of American Ethnic History, n. 25, 2006, pp. 7-32; BRUBAKER, Roger. The Return of Assimilation? Changing Perspectives on Immigration and Its Sequels in France, Germany and United States. In: Ethnic and Racial Studies, n. 24, 2001, pp. 531-548. 
os imigrantes abandonem seus costumes e práticas originais, adequando seu comportamento de acordo com os valores e as normas da maioria. Assim, devem mudar sua língua, vestimentas, estilos de vida e perspectivas culturais como parte da integração a uma nova sociedade. Segundo Harvey, nos Estados Unidos, conhecidos como uma "nação de imigrantes", gerações de imigrantes foram submetidas a pressões para se "assimilarem" dessa forma e muitos dos seus filhos se tornaram "americanos" mais ou menos completos como resultado disto. Também de acordo com o mesmo autor, a maioria das políticas oficiais do Reino Unido visa à assimilação de imigrantes à sociedade britânica ${ }^{13}$.

Recolhendo algumas das discussões teóricas derivadas, em princípio, da observação dos fatos mais que das filosofias, das políticas ou das normatizações relativas à integração, não passa despercebido no universo acadêmico norteamericano o contraste entre os defensores de um modelo de assimilação linear ${ }^{14}$ e de um modelo de assimilação segmentada ${ }^{15}$.

\section{A ASSIMILAÇÃO LINEAR}

Para os primeiros, numa perspectiva teleológica que vem descrever a inevitabilidade da integração, os processos integracionistas da população estrangeira estão se produzindo de forma bastante otimista, com uma exitosa incorporação dos imigrantes na mainstream americana. Este modelo clássico assimilacionista dá pouca margem ao manejo da diversidade, na medida em que acentua que os imigrantes se orientam principalmente à sociedade receptora $\mathrm{e}$ incorporam novos valores e práticas sociais próprias da sociedade de destino migratório e, ao mesmo tempo, vão despojando-se de elementos socioculturais 13 HARVEY, David, Sociologia, p. 460.

14 ALBA, R. Immigration and the American Realities of Assimilation and Multiculturalism. In: Sociological Forum, v. 14, 1999, pp. 3-25; ALBA, R. Remaking the American Mainstream: Assimilation an the New Immigration. Cambridge, MA: Harvard University Press, 2003; ALBA, R.; NEE, V. Rethinking Assimilation Theory for a New Era of Immigration. In: International Migration Review, v. 31, n. 4, pp. 826-874, 1997;

15 PORTES, A.; ZHOU, M. The New Second Generation: Segmented Assimilation and its Variantes. In: Annals of American Academy of Political and Social Science, 530, 1993, pp. 74-96; PORTES, A.; RIVAS, A. The Adptation of Migrant Children. In: The Future of Children, v. 21, n. 1, 2011, pp. 219-246; HALLER, W.; PORTES, A.; LYNCH, S.M. Dreams Fullfilled, Dreams Shatered: Determinants of Segmented Assimililation in the Second Generation. In: Social Forces, v. 89, n. 3, 2011, pp. 733-762. 
identificativos de suas origens.

Alguns autores, propagadores de um alarmismo desnecessário, chegam a sugerir a necessidade de uma clara assimilação forçada ${ }^{16}$ ou a certo neoevolucionismo com o qual parecem manejar-se alguns diagnósticos sobre o grau de integração identificado, que colocam de forma muito otimista a integração dos imigrantes ${ }^{17}$, contrastando fortemente com os defensores da teria da assimilação segmentada.

\section{A ASSIMILAÇÃO SEGMENTADA}

A noção de assimilação segmentada ${ }^{18}$ contempla expressamente, noutro sentido, a diversidade dos caminhos e das trajetórias da integração. Constatamse empiricamente os diferentes percursos que a população migrante, e muito especialmente os filhos dos imigrantes, traça em seus processos de integração. Por isso, devido à própria diversidade constatada nos itinerários que segue a população migrante, não resulta estranha a formulação do termo assimilação segmentada, em referência a dois fatores: por uma parte, em razão do fato de que a população migrante tende basicamente a assimilar-se ou a adaptar-se aos Estados Unidos quando chega, assim como seus filhos; por outra, e aqui se marca a diferença principal com a ideia de assimilação linear, que a adaptação se produz em diversas direções, daí a segmentação, às vezes, encaminhandose mais ao êxito social, outras vezes mais ao fracasso. Os imigrantes tendem à integração na sociedade americana, mas seus modelos e pautas divergem.

A questão da assimilação segmentada, especialmente ligada à integração das chamadas "segundas gerações" de imigrantes, não passou despercebida

16 HUNTINGTON, Samuel P. Who Are We? The Challenges to America's National Identity. New York: Simon and Schuster, 2004.

17 KASINITZ, P.; HOLLENKOPF, J.H.; WATERS, M.C. Becoming American/Becoming New Yorkers: Immigrant Incorporation in a Majority Minority City. In: International Migration Review, v. 36, n. 4, 2002, pp. 1020-1036; ALBA, R. Immigration and the American Realities of Assimilation and Multiculturalism; WATERS, M.; TRAN, V. C.; KASINITZ, P.; MOLENKOPF, J. H. Segmented Assimilation Revisited: types of acculturation and socioeconomic mobility in young adulthood. In: Ethnic and Racial Studies, v. 33, n. 7, pp. 1168-1193, 2010.

18 PORTES, A.; ZHOU, M. The New Second Generation: Segmented Assimilation and its Variantes.; PORTES, A. ; RUMBAUT, R. G. Ethnicities, Children of Immigrantes in America. Nova Iorque: University of California Press- Russel Sage Foundation, 2001. 
tampouco nos debates europeus ${ }^{19}$. O eixo desses autores ao descrever os processos de adaptação das segundas gerações situa-se em torno do conceito de "integração", termo que se usa em primeiro plano.

\section{O MODELO DO "MELTING POT"20}

Este modelo propõe que, em vez das tradições dos imigrantes se dissolverem em favor das dominantes entre a população preexistente, elas são mescladas e formam padrões culturais novos e evoluídos. Com suas atrações para uma variedade diversa de grupos étnicos, diz-se que os Estados Unidos são a melhor demonstração do padrão associado à ideia do melting pot. À medida que os grupos étnicos se adaptam aos ambientes sociais mais amplos em que se encontram, não apenas são "trazidos" valores e normas culturais diferentes de fora da sociedade, como também se cria mais diversidade ${ }^{21}$.

Muitos acreditam que o modelo do melting pot é o resultado mais desejável de integração em sociedades com diversidade étnica. As tradições e os costumes das populações imigrantes não são abandonados, mas contribuem e definem um meio social em constante transformação. Formas híbridas de culinária, moda, música e arquitetura são manifestações da abordagem melting pot. Até certo grau, segundo Harvey, esse modelo é a expressão exata de certos aspectos do desenvolvimento cultural norte-americano. Embora a cultura "anglo" tenha permanecido proeminente, seu caráter reflete, em parte, o impacto dos muitos grupos diferentes que hoje compõem a população norte-americana ${ }^{22}$.

Com uma considerável margem de certeza, é possível afirmar que o processo de integração ocorrido no Brasil possui algumas características que o aproximam do modelo melting pot, ainda que não se possa falar de um modelo puro desta

19 CRUL, M.; VERMEULEN, H. The Second Generation in Europe. In: International Migration Review, v. 37, n. 4, pp. 965-986, 2003.

20 Lugar de reconstrução e de violenta mistura; mistura de raças; cadinho; crisol.

21 BUREAU OF CENSUS (U. S. DEPARTMENT OF COMMERCE). Celebrating Our Nation's Diversity. Washington D.C., s.d.; JACOBY, Tamar. Defining Assimilations for the 21th Century. In: JACOBY, Tamar (Ed.). Reinventing the Melting Pot. New York: Basic Books, 2004; GANS, Herbert J. The American Kaleidoscope: Then and Now. In: JACOBY, Tamar (Ed.). Reinventing the Melting Pot. New York: Basic Books, 2004.

22 HARVEY, David, Sociologia, p. 460. 
natureza para explicar a configuração de diferentes sociedades hibridizadas. Esta análise pode bem ser amparada em Darcy Ribeiro, cuja reflexão demonstra que não ocorreu no Brasil nada parecido com o que sucedeu nos países rio-platenses, onde uma etnia original numericamente pequena foi submetida por massas de imigrantes que, representando quatro quintos do total, imprimiram uma fisionomia nova, caracteristicamente europeia, à sociedade e à cultura nacional, transfigurando-os de povos novos em povos transplantados. No Brasil, segundo este antropólogo, "o Brasil nasce e cresce como um povo novo, afirmando cada vez mais essa característica em sua configuração histórico-cultural"23. O assinalável no caso brasileiro, segundo Ribeiro, é, por um lado, a desigualdade social, expressa radicalmente na estratificação pela posição inferiorizada do negro e do mulato. E, por outro lado, a homogeneidade cultural básica, que transcende tanto as singularidades ecológicas regionais, bem como as marcas decorrentes da variedade de matrizes raciais, como as diferenças oriundas da proveniência cultural dos distintos contingentes ${ }^{24}$.

\section{O MODELO DO PLURALISMO CULTURAL}

O terceiro modelo de integração étnica é o do pluralismo cultural, segundo o qual as culturas étnicas têm validade plena para existir separadamente, mas devem participar da vida econômica e política da sociedade maior. Este é um modelo que pode ser situado, tanto fática quanto teoricamente, a partir da década de $1960^{25}$. Nesta época teve início uma grande revolução comportamental como o surgimento do feminismo e os movimentos civis em favor dos negros e dos homossexuais.

23 RIBEIRO, Darcy. O Povo Brasileiro. A formação e o sentido do Brasil. 3. ed. São Paulo: Companhia das Letras, 1995, p. 242-243.

24 RIBEIRO, Darcy. O Povo Brasileiro. A formação e o sentido do Brasil, p. 243.

25 Ver a respeito KYMLICKA, Will. Ciudadanía multicultural. Una teoría liberal de los derechos de las minorias. Traducción de Carme Castells Auleda. Barcelona: Paidós, 1996; KYMLICKA, Will. Estados, naciones y culturas. Traducido y adaptado por Juan Jesús Mora. Córdoba: Editorial Almuzara, 2004; KYMLICKA, Will. La política vernácula. Nacionalismo, multiculturalismo y ciudadanía. Traducción de Tomás Fernandéz Aúz y Beatriz Eguibar. Barcelona: Paidós, 2003; KYMLICKA, Will; STRAEHLE, Cristiane. Cosmopolitismo, Estado-nación y nacionalismo de las minorías. Un análisis crítico de la literatura reciente. México: Universidad Autónoma de México, 2001; KYMLICKA, Will. Multiculturalismo Liberal e direitos Humanos. In: SARMENTO, Daniel; IKAVA, Daniela; PIOVESAN, Flávia.

Igualdade, diferença e Direitos Humanos. Rio de janeiro: Lúmen júris, 2008. 
Esta situação é bem compreendida por Hobsbawn, em The Age of Extremes, ao localizar com precisão as mudanças extraordinárias que se desenvolveram no último terço do século XX. Era um mundo em que os comentadores das mais diferentes vertentes políticas referiam-se à "bússola" que não estava funcionando, em que cada certeza aparente da sociedade - a família, o trabalho, a nação e mesmo a própria afluência - foi questionada ${ }^{26}$. O que é preciso destacar, dentro do foco deste trabalho, a partir de Hobsbawn, é a emergência de um mundo completamente diferente em sua configuração, já não mais homogêneo, mas com uma ampla fragmentação que emergiu também sob a faceta cultural, tanto no plano territorial das cidades como dos próprios Estados. O mundo começava a sair de uma configuração mundial bipolarizada, homogeneizada, para novas formas de representação muito mais complexas, multifacetadas, multiculturalizadas. Da homogeneidade emergia a multiculturalidade.

Os movimentos multiculturalistas que iniciaram nos anos 60 do século passado aumentaram significativamente com a queda do muro de Berlim, evento após o qual todas as sociedades do bloco comunista passaram a conviver com reclamações por respeito às diferenças, especialmente étnicas - e a questão da Bósnia talvez seja o mais sensível desses $\operatorname{casos}^{27}$. O que todos esses movimentos tinham em comum era a necessidade de reconhecimento de suas diferenças culturais. Não desejavam - salvo em casos bem pontuais - que as especificidades de sua própria cultura suplantassem definitivamente o ideal nacional já estabelecido, ou mesmo que seus membros fossem considerados apartados do cenário cultural do Estado-nação. Apenas desejavam ser reconhecidos dentro da nação à qual pertenciam, como portadores de características particulares que os diferenciavam da população ainda adstrita à ideia de cidadania nacional ${ }^{28}$.

Não é nenhum delírio de importância destacar que a pluralidade cultural é, na contemporaneidade, uma realidade e uma virtude das sociedades democráticas

26 HOBSBAWN, Eric. The Age of Extremes. London: Michael Joseph, 1994; YOUNG, Jock. A sociedade excludente. Exclusão social, criminalidade e diferença na modernidade recente. Rio de Janeiro: Revan, 2002.

27 PAREKH, Bhikhu. Repensando el multiculturalismo. Diversidad cultural y teoría política. Traducción de Sandra Chaparro. Madrid: Istmo, 2000.

28 SEMPRINI, Andrea. Multiculturalismo. Tradução de Laureano Pelegrin. Bauru: EDUSC, 1999. 
que devem ser estimuladas. Assim, o fato de diferentes culturas postularem o mesmo direito de exercerem, num mesmo país, as suas diferenças, exige dos direitos humanos uma espécie de mediação entre a igualdade e a diferença que sua universalidade comporta ${ }^{29}$.

\section{MODELOS DE GOVERNABILIDADE MIGRATÓRIA OU DE POPULAÇÕES MIGRANTES AOS PAÍSES E SOCIEDADES DE DESTINO}

\section{O MODELO DA "SECURITIZAÇÃO"}

Este modelo tem como centro das políticas migratórias a segurança nacional, social e cultural do país receptor. As políticas migratórias se estruturam como parte da segurança nacional e com base na doutrina que a sustenta. A partir do eixo central deste modelo se desenvolvem as mais avançadas tecnologias de controle de fronteiras e residência de estrangeiro ${ }^{30}$.

Dentro dessa visão da segurança, o migrante é visto como uma ameaça potencial devido a sua possível vinculação com o terrorismo internacional ou ao narcotráfico ou à delinquência em geral. Esta ameaça se estende também à cultura ou às formas de vida do país receptor, na medida em que o migrante mantenha seus hábitos culturais, língua ou religião, se estas não são as mesmas que as predominantes no lugar de recepção ${ }^{31}$.

Os direitos dos migrantes se restringem, nesta perspectiva, à sua condição de regularidade ou nacionalidade. A irregularidade é considerada sinônimo

29 ALCALÁ, J. Alberto del Real. Problemas de gestión de la diversidad cultural en un mundo plural. In: RUIZ, Ruiz Ramón et al. (Editores). Derechos fundamentales, valores y multiculturalismo. Madrid: Dykinson, 2005; TORRE, Giuseppe Dalla. La multiculturalità come dato di fatto e come programma etico-politico. In: TORRE, Giuseppe Dalla; D'AGOSTINO, Francesco (Orgs.). La cittadinanza. Problemi e dinamiche in una società pluralística. Torino: G. Giappichelli Editore, 2000.

30 MÁRMORA, Lelio. Modelos de Gobernabilidad Migratoria. La Perspectiva Política em América del Sur. In: Revista Internacional de Mobilidade Humana. Ano XVIII, n. 35, pp. 71-92, jul./dez. 2010,

31 HUNTINGTON, Samuel. ¿Quién somos? Los desafios de la identidade nacional estadounidense. Buenos Aires: Paidós, 2004. 
de ilegalidade e o migrante ilegal é considerado, em muitos países e regiões do mundo, como uma pessoa que está cometendo um delito pelo qual deve ser sancionado. Esta sanção vai desde detenção por determinado tempo até a deportação a seu país de origem ou onde seja recebido.

Quanto à nacionalidade, nesse modelo predomina a concepção de "unicidade", é dizer, a não possibilidade de manter simultaneamente diferentes nacionalidades.

\section{O MODELO DOS “BENEFÍCIOS COMPARTILHADOS”}

Este segundo modelo parte do princípio de que as migrações podem proporcionar benefícios tanto aos países de origem como de recepção, sempre que sejam ordenadas e regulares. A migração é segura se é regular. Portanto, neste modelo se incentivam as chamadas "migrações circulares" realizadas dentro de acordos de demanda e oferta. Esta perspectiva mantém a necessidade de igualdade de oportunidades e tratamento nos mercados de trabalho dos países receptores ${ }^{32}$.

\section{O MODELO DE “DESENVOLVIMENTO HUMANO PARA AS}

MIGRAÇÕES"

A estruturação deste modelo se dá sobre uma posição ética que considera os direitos da pessoa migrante como centro de toda política migratória. Rechaça a inclusão das políticas migratórias dentro da órbita das políticas de segurança e mantém a posição do direito à livre circulação, à residência, ao retorno e à justiça social para as pessoas migrantes. Este modelo não aceita a adjetivação de "ilegal" para o migrante em situação irregular, considerando esta uma infração administrativa e não um delito ${ }^{33}$.

32 MÁRMORA, Lelio. Modelos de Gobernabilidad Migratoria. La Perspectiva Política en América del Sur, p.77

33 MÁRMORA, Lelio. Modelos de Gobernabilidad Migratoria. La Perspectiva Política en América del Sur, p. 77. 


\section{COTEJANDO OS MODELOS DE INTEGRAÇÃO ÉTNICA E DE GOVERNABILIDADE MIGRATÓRIA E ALGUNS CONTEXTOS DE APLICAÇÃO}

As múltiplas questões que estão envolvidas na relação entre migrações e gestão da diversidade e da identidade fazem emergir distintos focos de atenção, na medida em que o fenômeno da integração apresenta-se multidimensional ${ }^{34}$. Assim, por exemplo, em relação à abordagem da integração dos imigrantes desde uma aproximação macro, a perspectiva costuma deter-se frequentemente em estudar as políticas de integração e refletir sobre os modelos de integração nos quais descansam, havendo sido bastante frequente a centralidade no debate de discussões acadêmicas entre a pertinência de modelos de integração de caráter assimilacionistas e pluralistas, em versões de multi e interculturalismo.

No contexto europeu, por meio da aprovação dos Princípios Básicos Comuns para a Integração dos Imigrantes (e correlatos como o Programa Inti ${ }^{35}$ ), decantase uma integração desde a perspectiva do interculturalismo ${ }^{36}$ e começa-se a trabalhar o desenvolvimento de um programa de Cidades Interculturais ${ }^{37}$, onde o interculturalismo implica não só o reconhecimento explícito do valor da diversidade, mas também a realização de todo o possível para incrementar a interação, a mescla, a hibridização entre comunidades culturais, política que se aproxima do modelo integracionista do melting pot e do modelo político de governabilidade voltado ao "desenvolvimento humano para as migrações".

Nessa aproximação macro centrada em políticas e modelos de integração, 34 GUALDA CABALLERO E. (Dir.). Hacia un "trabajo decente" para los extranjeros: Inserción sociolaboral de la población extranjera em Andalucia. Dirección General de Coordinación de Políticas Migratorias, Sevilla, 2007.

35 EUROPEAN COMISSION. Integration Fund. Disponível em: http://ec.europa.eu/homeaffairs/funding/integration/funding integration en.htm. Acesso em: 25 maio 2014

36 GUALDA CABALLERO, E. Las aportaciones positivas de la inmigración: Mirada desde Andalucia. Valencia: Diálogos, 2011; THE COUNCIL OF THE EUROPEAN UNION AND THE REPRESENTATIVES OF THE GOVERNMENTS OF THE MEMBERS STATES, Common Basic Principles for Immigrant Integration Policy in the European Union. Bruxelas. 2004. Disponível em: http://ec.europa.eu/home-affairs/funding/integration/funding_integration_ en. htm. Acesso em: 18 maio 2014.

37 COUNCIL OF EUROPE. Intercultural Cities. 2011. Disponível em: http://www.coe.int/ interculturalcities. Acesso em 25: nov. 2013. 
o eixo de atenção característico vem sendo político-normativo, destacando-se desde princípios básicos comuns para a integração, até o estabelecimento de princípios reitores em alguns planos para a integração os quais permitem conhecer as bases sobre as quais se sustentam os modelos de integração propostos.

Tomando em consideração que a diversidade étnica aporta um elemento adicional de complexidade aos fatores de diferenciação interna de qualquer sociedade, com implicações para sua gestão pública, a União Europeia se posicionou até o momento tentando reconhecer politicamente que a integração deve ser "bidirecional" 38 .

Essa concepção carrega consigo uma atribuição de responsabilidade pelo processo integrativo não só ao migrante, mas também à sociedade receptora que, segundo as experiências, por meio de alguns de seus segmentos, tem se posicionado de maneira diferente a algumas políticas de corte intercultural ou a algumas estratégias de aculturação e processos de integração que propiciam a interculturalidade, como assim põe em destaque a Social European Survey ou a Encuesta Social Andaluza ${ }^{39}$, bem como diversas pesquisas realizadas na Espanha ${ }^{40}$.

Uma das críticas mais fortes que tem sido feita na Espanha à ideia de assimilação reside precisamente no fato de que, no plano das políticas e dos modelos de integração, o conceito circunscreve-se unilateralmente e não toma em conta um sentido bidirecional nos processos de integração, pois mudam tanto a sociedade receptora quanto os imigrantes. Não obstante, a ideia de assimilação segmentada é entendida por alguns autores como circunscrita à descrição de diferentes situações

38 THE COUNCIL OF THE EUROPEAN UNION AND THE REPRESENTATIVES OF THE GOVERNMENTS OF THE MEMBER STATES. Common Basic Principles for Immigrant Integration Policy in the European Union.

39 GUALDA CABALLERO, E. Actitudes hacia las migraciones y capital social: la participación de los europeus en redes sociales y sus lazos con la mayor o menor aceptación de la población extranjera. In: Redes. Revista Hispana para el Análisis de las Redes Sociales, v. 7, n. 3, 2004. Disponível em: http://revista-redes.rediris.es. Acesso em: 30 out. 2013; GUALDA CABALLERO, E. Capital social, ciudadanía e integración social desde la perspectiva de las actitudes hacia la población exteanjera. In: ANDREU, J. (comp.). Desde la Esquina de Europa. Análisis Comparado del capital social em Andalucía, España y Europa. Biblioteca Nueva, Centro de Estudios Andaluces, 2007, pp. 197-238.

40 OBSERVATORIO PERMANENTE ANDALUZ DE LAS MIGRACIONES. Informe Anual Andalucia e Inmigración 2010. Dirección General de Coordinación de Políticas Migratorias, Sevilla, 2010. Disponível em: http://www.juntadeandalucia.es/empleo/OPAM. Acesso em: 23 nov. 2013. 
empiricamente localizadas nos Estados Unidos, mais que um modelo político de integração ${ }^{41}$. Assim, enquanto as referências a uma assimilação linear ou forçada vêm a ser equivalentes ao que no cenário europeu se costuma entender por assimilação (um processo unilateral mediante o qual o imigrante adapta-se ao caminho já traçado pela sociedade receptora), a ideia de assimilação segmentada reflete a diversidade real de modos de incorporação, afetados estes, por sua vez, pela funcionalidade, por exemplo, das políticas migratórias, das comunidades étnicas ou das estruturas familiares, além do capital humano do país.

Há autores europeus que preferem aludir a processos de integração diferenciada ${ }^{42}$, por entenderem que o termo assimilação está conotado muito negativamente ao ser equiparado às políticas de assimilação forçada, ainda que não se pode perder de vista que a noção de assimilação segmentada surge no contexto americano, em que se tem discutido nos últimos tempos sobre assimilação/multiculturalismo ${ }^{43}$ e sobre assimilação linear/segmentada ${ }^{44}$.

Ainda é preciso lembrar que, não obstante os avanços teóricos construídos especialmente na Europa, ainda persistem neste espaço geopolítico os discursos e as políticas de assimilação forçada, aos quais se pode associar diretamente elementos políticos e normativos de securitização no plano normativo nacional de alguns países como, por exemplo, Inglaterra, Itália e França, e até mesmo no próprio Pacto sobre Migração da União Europeia ${ }^{45}$.

41 GUALDA CABALLERO, E. Las aportaciones positivas de la inmigración: Mirada desde Andalucia.

42 SOLÉ, C.; IZQUIERDO, A. (Coords.). Integraciones Diferenciadas. Migraciones em Cataluña, Galicia y Andalucía. Barcelona: Antropos, 2005.

43 ALBA, R. (1999). Immigration and the American Realities of Assimilation and Multiculturalism.

44 KASINITZ, P.; HOLLENKOPF, J.H.; WATERS, M.C. Becoming American/Becoming New Yorkers: Immigrant Incorporation in a Majority Minority City. In: International Migration Review, v. 36, n. 4, pp. 1020-1036, 2002; ALBA, R.; NEE, V. Remaking the American Mainstream: Assimilation an the New Immigration; WATERS, M.; TRAN, V. C.; KASINITZ, P.; MOLENKOPF, J. H. Segmented Assimilation Revisited: types of acculturation and socioeconomic mobility in young adulthood. In: Ethnic and Racial Studies, v. 33, n. 7, pp. 1168-1193, 2010; PORTES, A.; ZHOU, M. The New Second Generation: Segmented Assimilation and its Variantes; PORTES, A.; RIVAS, A. The Adaptation of Migrant Children; HALLER, W.; PORTES, A.; LYNCH, S.M. Dreams Fullfilled, Dreams Shatered: Determinants of Segmented Assimililation in the Second Generation.

45 Ver a respeito SANTOS, A. L. C. A repressão das diásporas em tempos globais e os direitos humanos dos migrantes. 
Também é importante não esquecer que o modelo assimilacionista é adotado fortemente nas políticas de segurança nacional nos Estados Unidos. Aqui vale lembrar as famosas House Bills e Senate Bills estaduais, especialmente as House Bills (HB) 56 (Estado do Alabama), 87 (Estado da Geórgia) e a Senate Bill (SB) 1070 (Estado do Arizona, com vigência desde 29 de julho de 2011), as quais se constituíram, nos últimos tempos, como as mais duras legislações de repressão aos migrantes.

\section{SOBRE OS MODELOS DE INTEGRAÇÃO E AS POLÍTICAS DE GOVERNABILIDADE MIGRATÓRIA POSITIVADOS NO BRASIL}

A delimitação do recorte analítico, nesta parte final do presente trabalho, ao marco normativo brasileiro destinado aos processos migratórios deve-se, em primeiro lugar, ao fato de que o Brasil é um dos dois países, juntamente com a Argentina, que se constituem nos principais polos receptores dos processos migratórios, cujo destino seja a América do Sul; por segundo, porque a tendência brasileira, devido ao tamanho de sua economia, seja a de receber cada vez mais migrantes; terceiro, em razão de que o marco normativo do Brasil para os estrangeiros é um conjunto normativo completamente defasado em termos de direitos humanos e ainda mais em relação à tutela da diversidade criada a partir dos fluxos migratórios.

Quanto à importância do tema para o Brasil, os números que seguem demonstram a intensidade dos fluxos migratórios de chegada.

IMIGRAÇÃO BRASILEIRA PERÍODO 2010-2014 ${ }^{1}$

\begin{tabular}{|l|l|l|l|l|l|}
\hline Síntese por categoria & 2010 & 2011 & 2012 & 2013 & 2014 \\
\hline Permanentes & 2.247 & 2.686 & 2.938 & 2.959 & 783 \\
\hline Temporários & 53.224 & 66.391 & 64.282 & 59.428 & 9.746 \\
\hline Total & 55.471 & 69.077 & 67.220 & 62.387 & 10.529 \\
\hline
\end{tabular}


Tomando em conta esses dados, bem como considerando os atuais índices de crescimento econômico ${ }^{46}$, além do provável desenvolvimento de um processo de integração regional na América do Sul, a tendência é que a imigração só venha a crescer para o Brasil, de modo que um marco legislativo e institucional adequado a parâmetros de direitos fundamentais, para lidar como situações de mobilidade humana é, mais do que nunca, fundamental, especialmente pelo fato de que a legislação brasileira, como será visto adiante, está muito distante de parâmetros aceitáveis de respeito aos direitos humanos dos migrantes.

Trazer esses dados ao texto tem o fim de destacar que nos últimos anos o Brasil tem assistido a um novo processo de crescimento da população estrangeira, e que isto tem sido acompanhado de uma progressiva diversificação da origem dos estrangeiros que residem no país, respondendo ao fenômeno descrito anteriormente. Pelo tamanho da sua economia, o Brasil tornou-se um país atraente para imigração, passando a ser o local de destino de imigrantes de países vizinhos, como a Bolívia, e também grupos vindos de países mais distantes, como os chineses, que já somam em torno de 250 mil no Brasil. Embora o saldo migratório atual seja ainda francamente favorável à emigração, a imigração vem crescendo, e em 2009 a OIM estimava em 688.026 o número de imigrantes no Brasil, embora grande parte dos analistas trabalhe com um contingente de pelo menos 1 milhão de estrangeiros no Brasil, contando os indocumentados.

Quanto à Argentina, seria desnecessário frisar sua vocação política de fomento à migração, pois é um país que se constitui eminentemente por fluxos migratórios, tendo, portanto, um número muito maior que o Brasil de migrantes em sua composição populacional.

Assim, o que se coloca aqui como questões centrais a serem respondidas em relação às políticas migratórias do Brasil cinge-se a três pontos principais:

46 De acordo com as estimativas da CEPAL, o Paraguai lideraria o crescimento em 2013, com um aumento na taxa do PIB de 12,5\%, seguido pelo Panamá (7,5\%), Peru (5,9\%), Bolívia $(5,5 \%)$, Nicarágua $(5,0 \%)$ e o Chile (4,6\%). A Argentina cresceria 3,5\%, o Brasil 2,5\% e o México $2,8 \%$. É preciso lembrar que ainda que o Brasil ostente uma das mais baixas taxas de crescimento, não se pode deixar de considerar que pelo tamanho de sua economia e pela diversidade de sua população, continua a ser o país da região mais atrativo para os migrantes. Disponível em: http://www.eclac.cl/prensa/noticias/comunicados/9/50489/ TablaPIBEstudio_economico2013_PORT.pdf. Acesso em: 24 abr. 2014. 
primeiro, se essas políticas estão pautadas por parâmetros internacionais e constitucionais de direitos humanos; segundo, quais os modelos integrativo e de governabilidade adotados?; terceiro, se os marcos político e jurídico estão direcionados à gestão da diversidade.

\section{O MARCO NORMATIVO BRASILEIRO PARA REGULAÇÃO DAS MIGRAÇÕES E SEUS MODELOS FUNDACIONAIS}

O conjunto normativo brasileiro voltado aos migrantes distancia-se enormemente dos modelos reguladores que privilegiam a diversidade. Um primeiro elemento de análise que é preciso considerar para a elaboração de investigação do marco normativo brasileiro em relação à imigração, no ponto que toca os modelos político e de integração que o sustentam, diz respeito ao objetivo mais amplo pretendido pelo governo brasileiro no plano internacional nos últimos anos. Quanto a isto, a posição de Rossana Rocha Reis merece atenção. Entende esta autora que a compreensão e o manuseio com as migrações internacionais têm relação direta com o objetivo de defender e assegurar o protagonismo do país em fóruns regionais e multilaterais, dentro de um contexto internacional em que o tema é cada vez mais importante e controverso. Assim, nesta perspectiva, se a política em relação aos emigrantes e também aquelas de cunho regional já eram caracterizadas como forma de política externa, nos últimos anos não foi diferente com a política de imigração, o que, sob certo aspecto, explica a posição do país em relação às migrações no sentido mais amplo ${ }^{47}$.

A posição do Estado/governo brasileiro em relação aos fenômenos de mobilidade humana é um tanto paradoxal, para dizer o mínimo. Por um lado, tem-se no exterior algo em torno de 3,5 milhões de brasileiros emigrados, situação que tem provocado fortes reações do governo brasileiro em relação a demandas de respeito aos direitos humanos destas pessoas. Por outro, em relação aos imigrantes que chegam em terras brasileiras, podem-se observar situações

47 REIS, Rossana Rocha. A Política do Brasil para as Migrações Internacionais. In: Contexto Internacional, Rio de Janeiro, v. 33, n. 1, pp. 47-69, jan./jun. 2011. Disponível em: http://contextointernacional.iri.puc-rio.br/cgi/cgilua.exe/sys/start.htm?tpl=home. Acesso em 24 abr. 2014. 
bastante contraditórias. Em um sentido, foram realizadas três anistias no Brasil: a primeira em 1988, depois em 1998 e, por fim, entre 2009 e 2011, com base na Lei n. 11.961, sendo regularizados algo em torno de 40 mil estrangeiros, entre os quais mais de 17 mil bolivianos e 4 mil paraguaios. De outra mão, em movimento político contrário, ribombam-se posturas governamentais consistentes em ameaças de deportação e estipulam-se cotas exíguas de entrada no país, como, por exemplo, no caso dos haitianos, cujas razões de migrar são por demais conhecidas do Estado brasileiro.

Há, assim, como se pode notar, um lado humanitário, sem maiores regulações normativas, levado a cabo pelo Executivo, e outro totalmente securitário, cuja base é fundamentalmente normativa, especialmente por meio do Estatuto do Estrangeiro (Lei n. 6.815/80).

Não se pode deixar cair no esquecimento, numa análise política, que a "lei de estrangeiros", que regula a entrada e a permanência de imigrantes no Brasil foi criada em 1980, ainda na vigência do regime militar, e se insere na lógica da "segurança nacional" do período, política legislativa que é claramente perceptível em seu art. $2^{\circ}$, in verbis:

Art. $2^{\circ} \mathrm{Na}$ aplicação desta Lei atender-se-á precipuamente à segurança nacional, à organização institucional, aos interesses políticos, sócioeconômicos e culturais do Brasil, bem assim à defesa do trabalhador nacional.

A elaboração dessa lei, escoltando-se na análise de Rocha Reis, se deu em um momento em que o regime militar estava particularmente descontente com a "interferência" de religiosos estrangeiros em assuntos considerados de foro interno e buscava um mecanismo que facilitasse a expulsão de estrangeiros envolvidos em atividades políticas no país ${ }^{48}$.

Além desse fundamento autoritário-securitário da legislação brasileira de estrangeiros, outra forte crítica que a ela é dirigida fundamenta-se no fato de que muitas das disposições presentes nesta lei ainda em vigor estão na contramão da

48 REIS, Rossana Rocha. A Política do Brasil para as Migrações Internacionais, p. 59. 
materialidade relativa aos direitos humanos presentes na Constituição de $1988^{49}$, bem como em relação à "Convenção das Nações Unidas para a proteção de todos os trabalhadores migrantes e membros de suas famílias", de 1990.

Por outro lado, a Lei n. 9.474, de 22 de julho de 1997 (Lei de Refugiados) também pouco ou nada agrega em termos humanistas em relação ao problema da gestão da diversidade e da integração étnica entre migrantes estrangeiros e população nacional. Ainda que ratifique os termos da Convenção para os Refugiados de 1951, praticamente nada dispõe sobre alternativas de ações políticas governamentais para o fomento de políticas públicas integradoras.

Numa análise regional mais ampla, a anacronia da legislação brasileira de estrangeiros tem colocado o Brasil numa situação de isolamento num continente até mesmo em relação ao reconhecimento de direitos políticos aos estrangeiros. Apenas para lembrar, o direito ao voto dos migrantes já foi reconhecido por Argentina, Bolívia, Colômbia, Equador, México e Peru.

Apesardosesforçosempreendidospelopoderpúblico,especialmenteoExecutivo, materializados, por exemplo, nas anistias antes mencionadas, é preciso concordar com Sprandel e Patarra quando dizem que ainda não existe, de fato, no Brasil, uma política coerente e integrada com respeito às migrações internacionais ${ }^{50}$. E se se cotejar nossa legislação em relação aos modelos de integração e governabilidade, se verá que a única certeza é que nosso marco normativo consagra uma visão securitária, nacionalista e protecionista. Se se pensar um pouco mais distante em termos de proteção da diversidade, irá se cair no vazio, pois não há dispositivo algum em nossa legislação que permita qualquer garantia aos migrantes de que sua diversidade étnica e cultural será respeitada, quanto mais fomentada. Pela legislação brasileira, é perfeitamente possível afirmar que os direitos dos migrantes se restringem a sua condição de regularidade ou nacionalidade.

Apenas a título ilustrativo, vale mencionar a posição de vanguarda assumida política ${ }^{51}$ e normativamente pela Argentina. A imigração sempre foi um tema

49 ACNUR; IMDH; CDHM. Políticas públicas para as migrações Internacionais. Migrantes e refugiados. 2. ed. revista e atualizada. Brasília: ACNUR; IMDH; CDHM, 2007.

50 SPRANDEL, M.; PATARRA, N. Projeto: Perfis Migratórios. Brasil. Texto Preliminar/OIM. Brasília: 2009 (mimeo).

51 Não se pode deixar de destacar que no plano da ação política estatal, essa tendência de 
bastante caro aos sistemas político e jurídico argentino. Desde os primórdios da constituição do pensamento político-jurídico liberal argentino, com pensadores como Juan Bautista Alberdi, de inegável influência na construção do primeiro texto constitucional em 1853, a imigração foi tratada como uma condição necessária para a construção do país, fenômeno que não poderia depender dos nativos. Em sua obra "Bases y puntos de partida para la organización política de la República Argentina", nominado como "Acción civilizadora de Europa en las Repúblicas de Sud América", Alberdi sustenta que os países americanos devem se voltar para a Europa como fonte de cultura, comércio e população e, sobretudo, de futuro, em termos que chegam até o racismo aberto ${ }^{52}$. Ainda que a posição de Alberdi seja xenófoba, pois prioriza a migração europeia em detrimento dos povos originários para a construção do país, é importante destacar que esta preocupação secular argentina resultou num processo de amadurecimento institucional e normativo em relação à migração, resultando, por exemplo, na atual legislação migratória que está amplamente à frente da brasileira em termos de aproximação aos parâmetros mundiais de direitos e humanos, bem como em relação à questão da diversidade étnica e cultural na relação da população migrante com a população sedentária. Veja-se, a título de ilustração, o disposto nos art. 25 e 25 da Constituição de $1994^{53}$, bem como o disposto no art. $3^{\circ}$ da Lei

integração pluralista, desenvolvimentista e humanista do modelo normativo migratório argentino se traduziu, nos últimos 9 ou 10 anos, através do programa "Pátria Grande", num processo de efetiva regularização de mais de 700.000 migrantes. Outros países do continente também realizaram este mesmo tipo de ação (Equador, Colômbia, Brasil, Chile e Paraguai), mas nenhum com a magnitude da ação argentina.

52 ¿Quién conoce caballero entre nosotros que haga alarde de ser indio neto? ¿Quién casaría a su hermana o a su hija con un infanzón de la Araucania, y no mil veces con un zapatero inglés? En América todo lo que no es europeo es bárbaro: no hay más división que ésta: 1.0, el indígena, es decir, el salvaje; 2.0, el europeo, es decir, nosotros, los que hemos nacido en América y hablamos español, los que creemos en Jesus Cristo y no en Pillán (dios de los indígenas)... ¿De dónde le vendrá esto en lo futuro? Del mismo origen de que vino antes de ahora: de Europa ALBERDI, Juan Bautista. Bases y puntos de partida para la organización política de la República Argentina. 1852. Disponível em: http:// ecaths1.s3.amazonaws.com/uccuyoconstitucional/Bases\%20y\%20puntos\%20de\%20partida\%20para\%20la\%20organizacion\%20politica\%20de\%20la\%20Republica\%20Argentina. pdf. Acesso em: 24 fev. 2014.

53 Artículo 20 - Los extranjeros gozan en el territorio de la Nación de todos los derechos civiles del ciudadano; pueden ejercer su industria, comercio y profesión; poseer bienes raíces, comprarlos y enajenarlos; navegar los ríos y costas; ejercer libremente su culto; testar y casarse conforme a las leyes. No están obligados a admitir la ciudadanía, ni a pagar contribuciones forzosas extraordinarias. Obtienen nacionalización residiendo dos años continuos en la Nación; pero la autoridad puede acortar este término a favor del que lo solicite, alegando y probando servicios a la República. Artículo 25.- El Gobierno federal fomentará la 
n. 25.871, de 20 de janeiro de 2004, Lei de Migrações ${ }^{54}$.

\section{Considerações Finais}

Para uma melhor visão e compreensão da política migratória brasileira e do seu marco de regulação, é preciso lançar um olhar para fora. E ao lado tem-se um excelente parâmetro de avaliação. A posição brasileira no âmbito regionalizado do Cone Sul, especialmente em relação às realidades argentina e uruguaia, inobstante a proximidade geográfica, revela um absurdo distanciamento em termos de tratamento e gestão dos fenômenos de mobilidade urbana. A Argentina, com uma base jurídica que adota modelos que transitam entre o melting pot e a pluralidade cultural, em termos de integração, e modelo do desenvolvimento humano para as migrações, no que diz respeito à governabilidade das mobilidades humanas. Já o Brasil, ainda que tenha realizado algumas ações governamentais regularizadoras (anistias) em termos de migrações, ainda permanece com uma base jurídica que sustenta claramente um modelo securitário, nacionalista e claramente afrontador dos parâmetros internacionais de direitos humanos dos migrantes. Em relação à tutela e à gestão da diversidade étnica e cultural da população, considerando os contingentes de migrantes, a postura brasileira é inexistente. A pergunta que aqui se impõe sem resistência, diante da defasagem da posição brasileira em relação a este grave tema contemporâneo, diz respeito ao que será feito num futuro próximo, especialmente em termos de construção de um novo marco normativo migratório.

inmigración europea; y no podrá restringir, limitar ni gravar con impuesto alguno la entrada en el territorio argentino de los extranjeros que traigan por objeto labrar la tierra, mejorar las industrias, e introducir y enseñar las ciencias y las artes.

54 Articulo $3^{\circ}-$ Son objetivos de la presente ley:

a) Fijar las líneas políticas fundamentales y sentar las bases estratégicas en matéria migratoria, y dar cumplimiento a los compromisos internacionales de la República en materia de derechos humanos, integración y movilidad de los migrantes;

(...)

e) Promover la integración en la sociedad argentina de las personas que hayan sido admitidas como residentes permanentes;

f) Asegurar a toda persona que solicite ser admitida en la República procedimientos de admisión no discriminatorios en términos de los derechos y garantías establecidos por la Constitución Nacional, los tratados internacionales, los convenios bilaterales vigentes y las leyes;

g) Promover y difundir las obligaciones, derechos y garantías de los migrantes, conforme a lo establecido en la Constitución Nacional, los compromisos internacionales y las leyes, manteniendo en alto su tradición humanitaria y abierta con relación a los migrantes y sus familias; 
As políticas de controle dos fluxos de corpos foram e continuam sendo políticas pensadas dentro do marco do Estado-nação, ou, na melhor das hipóteses, dentro de espaços confederativos, como a União Europeia, com a tecnologia jurídica de controle do Estado de Direito. As políticas de controle mantêm-se sobre um conjunto de saberes totalmente nacionalistas, sedentários e localizados.

Entretanto, a realidade epocalmente particular dos fluxos próprios da globalização revela que estes são fenômenos que se manifestam, no plano empírico, muito além das fronteiras do Estado-nação, e no plano teórico, reclamam a ultrapassagem de qualquer tentativa de disciplinarização dogmática e de controle mediante sistemas jurídicos repressivos. Autores como Hily ${ }^{55}$, Martine ${ }^{56}$ e Patarra ${ }^{57}$, assim como estudos da CEPAL, indicam o crescimento das migrações a partir do final do século XIX, inclusive com o apoio e os subsídios dos Estados - emissores e receptores. Entretanto, foi no final do século XX que as migrações internacionais se intensificaram, com seu ápice na década de 1990, destacando-se os Estados Unidos, Alemanha, Canadá e Japão como os principais países receptores. Na última década, este fenômeno adquiriu uma magnitude transnacional/regional importante nos países de nossa região, especialmente em relação à Argentina, ao Brasil e ao Chile como países receptores de paraguaios, peruanos e bolivianos.

Por outro lado, é preciso que se tome em consideração que alguns países extremamente importantes na configuração político-econômica mundial da atualidade, como, por exemplo, China e a maior parte dos países europeus, passam por fenômenos de decréscimo de natalidade, o que poderá, num futuro próximo, ter significativos reflexos sobre a disponibilidade de mão de obra. Segundo o Relatório do IMI, a tendência fundamental para a definição das migrações é a taxa de natalidade de alguns países:

O declínio mundial das taxas de natalidade poderá vir a colocar em questão a hipótese de existência de um viveiro inesgotável de migrantes

55 HILY, M. As migrações contemporâneas: dos Estados e dos homens. In: Anais do Seminário Cultura e Intolerância, São Paulo, nov./2003.

56 MARTINE, G. Globalização inacabada: Migrações internacionais e pobreza no século 21. In: São Paulo em Perspectiva. v. 19, n.3, jul/set., 2005, pp. 3-22.

57 PATARRA, N.L. Migrações Internacionais de e para o Brasil Contemporâneo. In: São Paulo em Perspectiva. V.19, n.3, jul/set. 2005, pp. 23-33; PATARRA, N.L Migrações Internacionais: Teoria, políticas e movimentos sociais. In: Estudos Avançados, v. 20, n.57, 2006, pp. 7-24. 
laborais, prontos a deslocar-se para os países industrializados, com vista a prover às necessidades econômicas. À medida que os países forem avançando na transição demográfica, as suas taxas de dependência aumentarão nos próximos decênios. A médio e longo prazos, uma concorrência acrescida no acesso a mão-de-obra poderá transformar radicalmente as migrações mundiais e as respostas políticas de maneira dificilmente imaginável ${ }^{58}$.

A China, novo gigante industrial, é com sua fraca taxa de natalidade candidata a deficit de mão de obra importante, caso continue mantendo suas taxas de crescimento e restrição à natalidade. Esse mesmo relatório alerta ainda que, em longo prazo, regiões da América Latina e Norte da África podem sofrer consequências do rápido decréscimo das taxas de natalidade registradas nas ultimas décadas.

Como se comportará esse cosmopolitismo, cuja questão não é mais entre o nacional e o migrante, mas onde se vê o local se globalizar. Neste panorama, é indispensável o reconhecimento da alteridade e dos direitos humanos. No mundo inteiro há muitas incertezas em torno da presença de comunidades estrangeiras; percebe-se muita resistência ao outro, o que pode gerar, em curto prazo, conflitos de grandes proporções. Por exemplo, na Europa, confrontam-se o etnocentrismo e a tolerância ao outro. A questão premente é como atender às reivindicações e respeitar os direitos dos migrantes, frente às legislações baseadas no poder e na soberania de Estado-nações.

A mobilidade contemporânea traz, além do dinamismo das migrações internacionais, a ilegalidade, o tráfico de pessoas, a xenofobia e a usurpação dos diretos do migrante. Para o enfrentamento destes problemas, as ações não podem ser unilaterais, é necessário esforço conjunto de diálogo e cooperação, respeitando a soberania nacional, mas reconhecendo a complexidade das questões para organizar foros internacionais.

No Brasil, o último movimento para elaboração de uma legislação de estrangeiros consiste no Projeto de Lei n. 5655/2009, apresentado pelo Executivo, que atualmente está aguardando parecer do relator na Comissão de Relações 58 INTERNATIONAL MIGRATION INSTITUTE (IMI). Towards a New Agenda for Interna-

tional Migration Research. University of Oxford, 2006, p. 13. 
Exteriores e de Defesa Nacional da Câmara dos Deputados. Esta proposta legislativa praticamente nada muda em relação à legislação de estrangeiros ora em vigência, pois em sua essência mantém uma orientação securitária, ainda que em seu art. $2^{\circ}$ mencione que a sua aplicação deverá nortear-se pela política nacional de migração, garantia dos direitos humanos, interesses nacionais, socioeconômicos e culturais, preservação das instituições democráticas e fortalecimento das relações internacionais.

Cotejando essa disposição preliminar com outras que revelam as diretrizes e as finalidades do projeto, verifica-se claramente uma orientação nacionalista, que se expressa, por exemplo, por meio do disposto no art. $4^{\circ}$, cujo texto diz que "A política imigratória objetivará, primordialmente, a admissão de mãode-obra especializada adequada aos vários setores da economia nacional, ao desenvolvimento econômico, social, cultural, científico e tecnológico do Brasil, à captação de recursos e geração de emprego e renda, observada a proteção ao trabalhador nacional". Mais ainda. Se for acrescentado a este artigo o enunciado do art. $7^{\circ}$, o qual prevê uma série de restrições aos imigrantes, torna-se escancarada a orientação securitária desta proposta.

Em termos de gestão da diversidade gerada pelos fluxos migratórios, nada está previsto nessa proposição, mesmo em termos genéricos, ficando os migrantes ao alvedrio de suas ações e possibilidades solipsistas para a construção de um ambiente que lhe permita manter sua identidade étnico-cultural, ou pelo menos proteger-se contra violências simbólicas assimilacionistas que a destruam.

O que se revela nesse movimento de proposição legislativa é a manutenção de um conjunto de saberes no âmbito político de base nacionalista e no plano jurídico dentro dos marcos jurídicos do Estado de Direito clássico, cuja figura do nacional-sedentário assume total proeminência em relação ao estrangeironômade. Ou seja, em outras palavras, os modelos teórico-práticos que orientaram os formuladores da proposta é o mesmo que sempre esteve arraigado aos limites protetivos do Estado-nação. Em resumo, nada mudou. Mas quais os caminhos a seguir para efetivamente haver uma proposta de legislação migratória que considere uma realidade contemporânea das migrações? 
É preciso, antes de tudo, refazer os saberes sobre um fenômeno que nas últimas décadas mudou completamente sua face. Algumas linhas investigativas precisam ser mais bem exploradas diante desses câmbios que sofreram os processos migratórios em razão da globalização:

Em primeiro lugar, qualquer investigação que queira ter um mínimo de imanência ao mundo contemporâneo deve considerar que, conforme alerta Badie o enorme crescimento dos fluxos transnacionais, a proliferação das redes e o fracasso da relação cidadã que se verifica um pouco por todo o lado, enfraquecem inevitavelmente - em particular fora da Europa - o território do Estado-nação que, cada vez menos, pode ter pretensões a beneficiar a fidelidade prioritária dos indivíduos ${ }^{59}$. É preciso ter em conta que se formam tendências em que a multiplicidade parece triunfar sobre o uno, em que os nomadismos parecem ser tão cotidianos quanto os sedentarismos;

Segundo, é inevitável interpretar as migrações como parte integrante dos processos de transformação mundial mais do que como um problema a resolver. As investigações devem se concentrar sobre as relações recíprocas entre os processos migratórios e as transformações econômicas e sociais. É necessário estudar os dois lados da migração: na sua origem - as causas de sua gênese - e de outro, o acolhimento - nos problemas e nas políticas de integração60;

Também é forçoso articular os padrões migratórios atuais com as tendências históricas, analisandoascontinuidadeseas descontinuidades. As migrações devem ser reconhecidas como um processo, com continuidades temporais de décadas ou séculos, reconhecer este fato ajuda a entender as zonas de descontinuidade e suas características estruturais. É premente combater o mito de que as migrações são "anomalias" da modernidade ${ }^{61}$;

Numa plano socioantropológico, não há como não aproximar a compreensão das migrações ao nível micro das tendências ao nível macro. As análises devem contemplar as motivações à mobilidade desde a esfera individual, familiar, comunitária até as políticas macroeconômicas ${ }^{62}$;

59 BADIE, Bertrand. O Fim dos Territórios. Ensaios sobre a desordem internacional e sobre a utilidade social do respeito. Lisboa: Instituto Piaget, 1995.

60 INTERNATIONAL MIGRATION INSTITUTE (IMI). Towards a New Agenda for International Migration Research, p. 11.

61 INTERNATIONAL MIGRATION INSTITUTE (IMI). Towards a New Agenda for International Migration Research, p. 11.

62 INTERNATIONAL MIGRATION INSTITUTE (IMI). Towards a New Agenda for Interna- 
Numa perspectiva mais projetiva, torna-se importante olhar para o futuro desenvolvendo cenários de tendências migratórias e tomando em consideração as mudanças demográficas, econômicas e políticas. As transformações socioeconômicas globais têm relações recíprocas com as dinâmicas migratórias, este é o ponto de partida para traçar as tendências do cenário das migrações ${ }^{63}$;

No campo investigativo relacionado ao Estado de Direito, repensar a funcionalidade dos direitos fundamentais de nacionalidade e políticos, de forma a suavizar e facilitar o acesso a estas espécies de direitos aos migrantes que objetivem a permanência no território do país de destino;

É necessário também considerar a complexidade das sociedades contemporâneas, cada vez mais multiculturais, a fim de que possamos elaborar saberes capazes de gerar ações políticas inclusivas, a partir de diálogos interculturais. Como, em função dos fluxos migratórios, surgem comunidades em todo mundo cada vez mais diversificadas, a forma de gestão da diversidade torna-se um dos principais desafios para o futuro. Cidades bem-sucedidas e as sociedades do futuro serão mais e mais multiculturais. Assim, gerir e explorar o potencial da diversidade cultural para estimular a criatividade e a inovação e, consequentemente, gerar prosperidade econômica e uma melhor qualidade de vida, tornam-se desafios a serem enfrentados não só no futuro, mas já nos dias atuais. A diversidade pode ser um recurso para o desenvolvimento de uma cidade se o discurso público, as instituições e os processos da cidade, bem como o comportamento das pessoas, levar em conta a diversidade de forma positiva.

Ainda considerando a complexidade das sociedades contemporâneas, é de fundamental importância inserir as investigações dentro de marcos teóricos que contemplem soluções ligadas à cooperação econômica entre norte e sul, numa perspectiva diacrônica, pois os países sulistas, e mais especificamente da América Latina, têm muito contribuído com os desafogamentos populacionais históricos que o norte do planeta precisou fazer, em função de crises econômicas, como forma de equilibrar suas economias. É chegada a hora de pensar fluxos humanos como alternativas de desenvolvimento tanto para países desenvolvidos como para os não-desenvolvidos e os em desenvolvimento;

No campo de constituição de um pensamento latino-americano, tornase importantíssimo pensar/considerar os fenômenos regionalizados 
de mobilidade humana, a fim de possibilitar-se a elaboraração de um campo de imanência teórica que permita territorializar soluções adequadas às demandas regionais reais, e não simplesmente repetir soluções alienígenas, especialmente do norte do planeta.

Para finalizar, vale considerar a recomendação da CEPAL, de que a globalização tornará cada vez mais necessário o trânsito do controle migratório para a gestão migratória num sentido amplo, o que não significa que os Estados abandonem sua atribuiç̧ão de regulamentar a entrada de estrangeiros e acautelar suas condições de radicação, mas que aceitem formular políticas razoáveis de admissão, que contemplem a permanência, o retorno, a reunificação familiar, a revinculação, o trânsito fronteiriço e o translado de indivíduos a outros países ${ }^{64}$.

\section{REFERÊNCIAS}

ACNUR; IMDH; CDHM. Políticas públicas para as migrações Internacionais. Migrantes e refugiados. 2. ed. revista e atualizada. Brasília: ACNUR; IMDH; CDHM, 2007.

ALBA, R. Immigration and the American Realities of Assimilation and Multiculturalism. In: Sociological Forum, v. 14, 1999, pp. 3-25.

; NEE, V. Rethinking Assimilation Theory for a New Era of immigration. In: International Migration Review, v. 31, n. 4, 1997, pp. 826-874.

Remaking the American Mainstream: Assimilation an the New Immigration. Cambridge, MA: Harvard University Press, 2003.

ALBERDI, Juan Bautista. Basesy puntos de partida parala organización política de la República Argentina, 1852. Disponível em : http://ecaths1.s3.amazonaws.com/uccuyoconstitucional/ Bases\%20y\%20puntos\%20de\%20partida\%20para\%20la\%20organizacion\%20politica\%20 de\%20la\%20Republica\%20Argentina.pdf. Acesso em: 24 fev. 2014.

ALCALÁ, J. Alberto del Real. Problemas de gestión de la diversidad cultural en un mundo plural. In: RUIZ, Ruiz Ramón et al. (Editores). Derechos fundamentales, valores y multiculturalismo. Madrid: Dykinson, 2005.

BADIE, Bertrand. O Fim dos Territórios. Ensaios sobre a desordem internacional e sobre a

64 CEPAL/NACIONES UNIDAS. Globalização e Desenvolvimento. 2002, p. 267. Disponível em: http://www.eclac.cl/publicaciones/xml/9/10029/GlobalizacionPortuguesCap8.pdf. Acesso em: 30 abr. 2014. 
utilidade social do respeito. Lisboa: Instituto Piaget, 1995.

BARKAN, Elliot. Race, Religion and Nationality in American Society: A Model of Ethnicity-From Contact to Assimilation. In: Journal of American Ethnic History, n. 14, 1995, pp. 38-101.

BARKAN, Elliot. Introduction: Immigration, Incorporation, Assimilation and the Limits of Transnationalism. In: Journal of American Ethnic History, n. 25, 2006, pp. 7-32

BRETTEL, Caroline B.; HOLLIFIELD, James F. (Eds.). Migration Theories of International Migration: A Review and Appraisal Theory. Talking Across Disciplines. 2. ed. New York/ London: Routledge, 2008.

BRUBAKER, Roger. The Return of Assimilation? Changing Perspectives on Immigration and Its Sequels in France, Germany and United States. In: Ethnic and Racial Studies, n. 24, 2001, pp. 531-548.

BUREAU OF CENSUS (U. S. DEPARTMENT OF COMMERCE). Celebrating Our Nation's Diversity. Washington D.C., s.d.

CEPAL/NACIONES UNIDAS. Globalização e Desenvolvimento. 2002. Disponível em: http:// www.eclac.cl/publicaciones/xml/9/10029/Globalizacion PortuguesCap8.pdf. Acesso em: 30 abr. 2014.

COUNCIL OF EUROPE Intercultural Cities. 2011. Disponível em: http://www.coe.int/ interculturalcities. Acesso em: 25 nov. 2013.

CRUL, M.; VERMEULEN, H. The Second Generation in Europe. In: International Migration Review, v. 37, n. 4, 2003, pp. 965-986.

EUROPEAN COMISSION. Integration Fund. Disponível em: http://ec.europa.eu/home-affairs/ funding/integration/funding_integration_en.htm Acesso em: 25 maio 2014

FUNDAÇÃO GETÚLIO VARGAS. A Imigração como Vetor Estratégico de Desenvolvimento Socioeconômico e Institucional do Brasil. Estudos Estratégicos sobre Políticas Públicas. Rio de Janeiro: FGV, s.d., v. 1. Disponível em: www.fgv.br/fgvprojetos e/ou www.dapp.fgv.br .Acesso em: 15 maio 2014.

GANS, Herbert J. The American Kaleidoscope: Then and Now. In: JACOBY, Tamar (ed.). Reinventing the Melting Pot. New York: Basic Books, 2004.

GRIMBERG, L.; GRIMBERG, R. Migración y Exilio. Estudio psicoanalítico. Madrid: Editorial Biblioteca Nueva, S. L., 1996. 
GUALDA CABALLERO, E. Actitudes hacia las migraciones y capital social: la participación de los europeus em redes sociales y sus lazos com la mayor ou menor aceptación de la población extranjera. In: Redes. Revista Hispana para el Análisis de las Redes Sociales, v. 7, n. 3, 2004. Disponível em: http://revista-redes.rediris.es. Acesso em: 30 out. 2013.

Capital social, ciudadanía e integración social desde la perspectiva de las actitudes hacia la población exteanjera. In: ANDREU, J. (comp.). Desde la Esquina de Europa. Análisis Comparado del capital social em Andalucía, España y Europa. Biblioteca Nueva, Centro de Estudios Andaluces, 2005, pp. 197-238.

. Las aportaciones positivas de la inmigración: Mirada desde Andalucia. Valencia: Diálogos, 2011.

. (Dir.). Hacia un "trabajo decente" para los extranjeros: Inserción sociolaboral de la población extranjera em Andalucia. Dirección General de Coordinación de Políticas Migratorias, Sevilla, 2007.

HALLER, W.; PORTES, A.; LYNCH, S.M. Dreams Fullfilled, Dreams Shatered: Determinants of Segmented Assmililation in the Second Generation. In: Social Forces, v. 89, n. 3, pp. 733-762, 2011.

HARVEY, David. Sociologia. 6. ed. Porto Alegre: Penso, 2012.

HILY, M. As migrações contemporâneas: dos Estados e dos homens. In: Anais do Seminário Cultura e Intolerância. São Paulo, nov. 2003.

HOBSBAWN, Eric. The Age of Extremes. London: Michael Joseph, 1994.

HUNTINGTON, Samuel P. Who Are We? The Challenges to America's National Identity. New York: Simon and Schuster, 2004.

INTERNATIONAL MIGRATION INSTITUTE (IMI). Towards a New Agenda for International Migration Research. University of Oxford, 2006.

JACOBY, Tamar. Defining Assimilations for the 21th Century. In: JACOBY, Tamar (Ed.). Reinventing the Melting Pot. New York: Basic Books, 2004.

KAES, R. et al. Crise, Rupture et Depassement. Paris: Dunod, 1979.

KASINITZ, P.; HOLLENKOPF, J.H.; WATERS, M.C. Becoming American/Becoming New Yorkers: Immigrant Incorporation in a Majority Minority City. In: International Migration Review, v. 36, n. 4, pp. 1020-1036, 2002. 
KEELEY, Brian. The Migration Debate. International Migration: The Human Face of Globalization. OECD Publishing, 2009. Disponível em: http://www.oecd-ilibrary.org/socialissues-migration-health/international-migration_9789264055 780 -em. Acesso em: 29 nov. 2013.

KUREKOVA, Lucia. Theories of migration: Conceptual review and empirical testing in the context of the EU East-West flows. London: University College London, 2011

KYMLICKA, Will. Ciudadanía multicultural. Una teoría liberal de los derechos de las minorias. Traducción de Carme Castells Auleda. Barcelona: Paidós, 1996.

. Estados, naciones y culturas. Traducido y adaptado por Juan Jesús Mora. Córdoba: Editorial Almuzara, 2004.

La política vernácula. Nacionalismo, multiculturalismo y ciudadanía. Traducción de Tomás Fernandéz Aúz y Beatriz Eguibar. Barcelona: Paidós, 2003.

;STRAEHLE, Cristiane. Cosmopolitismo, Estado-nación y nacionalismo de las minorías. Un análisis crítico de la literatura reciente. México: Universidad Autónoma de México, 2001.

Multiculturalismo Liberal e direitos Humanos. In: SARMENTO, Daniel; IKAVA, Daniela; PIOVESAN, Flávia. Igualdade, diferença e Direitos Humanos. Rio de janeiro: Lúmen júris, 2008.

LYNCH, S.M. Dreams Fullfilled, Dreams Shatered: Determinants of Segmented Assmililation in the Second Generation. In: Social Forces, v. 89, n. 3, pp. 733-762, 2011.

MARTINE, G. Globalização inacabada: Migrações internacionais e pobreza no século 21. In: São Paulo em Perspectiva. v.19, n.3, pp. 3-22, jul/set., 2005.

MASSEY, Douglas S., ARANGO, Joaquin et alli. Theories of International Migration: A Review and Appraisal. In: Population and Development Review, v. 19, n. 3, pp. 431-466, sep. 1993.

MINISTÉRIO DO TRABALHO E EMPREGO. Base Estatística. Coordenação Geral de Imigração. Disponível em: http://portal.mte.gov.br/trab_estrang/ estatisticas.htm. Acesso em: 25 abr. 2014.

OBSERVATORIO PERMANENTE ANDALUZ DE LAS MIGRACIONES (2010). Informe Anual Andalucia e Inmigración 2010. Dirección General de Coordinación de Políticas Migratorias, Sevilla, 2010. Disponível em: http://www.juntadeandalucia.es/empleo/OPAM. Acesso em: 23 nov. 2013. 
PAREKH, Bhikhu. Repensando el multiculturalismo. Diversidad cultural y teoría política. Traducción de Sandra Chaparro. Madrid: Istmo, 2000.

PATARRA, N.L. Migrações Internacionais de e para o Brasil Contemporâneo. In: São Paulo em Perspectiva. v.19, n.3, pp. 23-33, jul/set. 2005;

. Migrações Internacionais: Teoria, políticas e movimentos sociais. In: Estudos Avançados, v. 20, n.57, pp. 7-24, 2006.

PORTES, A.; ZHOU, M. The New Second Generation: Segmented Assimilation and its Variantes. In: Annals of American Academy of Political and Social Science, 530, pp. 74-96, 1993.

. RIVAS, A. The Adptation of Migrant Children. In: The Future of Children, v. 21, n. 1, pp. 219-246, 2011.

RUMBAUT, R. G. Ethnicities, Children of Immigrantes in America. Nova Iorque: University of California Press- Russel Sage Foundation, 2001.

REIS, Rossana Rocha. A Política do Brasil para as Migrações Internacionais. In: Contexto Internacional, Rio de Janeiro. v. 33, n. 1, jan./jun. 2011. Disponível em: http:// contextointernacional.iri.puc-rio.br/cgi/cgilua.exe/sys/ start.htm?tpl=home. Acesso em: 24 abr. 2014.

RIBEIRO, Darcy. O Povo Brasileiro. A formação e o sentido do Brasil. 3. ed. São Paulo: Companhia das Letras, 1995.

SANTOS, A. L. C. A repressão das diásporas em tempos globais e os direitos humanos dos migrantes. In: BEDIN, Gilmar Antonio (Org.). Cidadania, Direitos Humanos e Equidade. Ijuí: Editora UNIJUÍ, 2012.

SEMPRINI, Andrea. Multiculturalismo. Tradução de Laureano Pelegrin. Bauru: EDUSC, 1999.

SOLÉ, C.; IZQUIERDO, A. (Coords.). Integracionees Diferenciadas. Migraciones em Cataluña, Galicia y Andalucía. Barcelona: Antropos, 2005.

SOLIMANO, Andrés. International Migrations in the Age of Crisis and Globalizations. Historical and Recent Experiences. Cambridge: Cambridge University Press, 2010.

SPRANDEL, M.; PATARRA, N. Projeto: Perfis Migratórios. Brasil. Texto Preliminar/OIM. Brasília: 2009 (mimeo).

THE COUNCIL OF THE EUROPEAN UNION AND THE REPRESENTATIVES OF THE GOVERNMENTS OF THE MEMBER STATES. Common Basic Principles for Immigrant Integration Policy in 
the European Union. Bruxelas, 2004. Disponível em: http://ec.europa.eu/ewsi/en/EU_actions_ integration.cfm. Acesso em: 18 maio 2014.

TORRE, Giuseppe Dalla. La multiculturalità come dato di fatto e come programma eticopolitico. In: TORRE, Giuseppe Dalla; D'AGOSTINO, Francesco (Orgs.). La cittadinanza. Problemi e dinamiche in una società pluralística. Torino: G. Giappichelli Editore, 2000.

VERTOVEC, Steven. "Superdiversity' and its implications". In: Ethnic and racial studies, v. 30, n. 6, pp. 1024-1054, 2007.

WATERS, M.; TRAN, V. C.; KASINITZ, P.; MOLENKOPF, J. H. Segmented Assimilation Revisited: types of acculturation and socioeconomic mobility in young adulthood. In: Ethnic and Racial Studies, v. 33, n. 7, pp. 1168-1193, 2010.

YOUNG, Jock. A sociedade excludente. Exclusão social, criminalidade e diferença na modernidade recente. Rio de Janeiro: Revan, 2002.

1 MINISTÉRIO DO TRABALHO E EMPREGO. Base Estatística. Coordenação Geral de Imigração. Disponível em: http://portal.mte.gov.br/trab estrang/estatisticas.htm. Acesso em: 25 abr. 2014. Dados atualizados até 31/03/2014. 